\title{
Physicochemical and microbial quality of cow and buffalo raw milk collected from different organized dairy farms of Varanasi, India
}

\author{
Dwarki Lal ${ }^{1}$, Dinesh Chandra Rai ${ }^{1}$, Arvind ${ }^{1}$, Vinod Bhateshwar ${ }^{1}$ and Hitesh Muwal ${ }^{2}$
}

Received: 06 June 2021 / Accepted: 15 July 2021 / Published online: 07 September 2021

(c) Indian Dairy Association (India) 2021

\begin{abstract}
The current study was carried out to estimate the physicochemical properties, microbial quality, and adulteration pattern of cow and buffalo raw milk collected from different organized dairy farms in Varanasi, India. Raw milk samples were analyzed and found that the cow's raw milk constituents i.e. the per cent of lactose $(4.31)$ was significantly $(\mathrm{P}<0.05)$ different whereas fat (3.76), protein (3.37) solid not-fat (8.51), and specific gravity (1.028) were observed non-significant among collected samples. However, the percent of fat (6.63), protein (4.17), and specific gravity $(1.029)$ were recorded significantly $(\mathrm{P}<0.05)$ different but the average percentage of lactose (4.81) and solid not-fat (8.95) was noted non-significantly different in the raw milk of buffalo. All raw milk samples were of good quality grades as determined by the MBRT test. The microbial count confirmed the presence of significantly $(\mathrm{P}<0.05)$ low microbial load in all cow (3.53 log CFU/ml) as well as in buffalo raw milk (3.46 log $\mathrm{CFU} / \mathrm{ml}$ ) samples. In adulterations analysis; all raw milk samples were free from water, starch, cane sugar, and glucose. Besides different hazardous chemical adulterants, all raw milk samples were free from urea, hydrogen peroxide, ammonium, and nitrates.
\end{abstract}

Keywords: Adulterant; Buffalo; Cow; Dairy farm; Microbial quality; Raw milk

Milk is a supplement diet in various parts of the world which is obtained from different animal species such as goat, cow, buffalo, and camel. It is also a necessary source of a great variety of

\footnotetext{
${ }^{1}$ Department of Dairy Science and Food Technology, Institute of Agricultural Sciences, Banaras Hindu University, Varanasi- 221 005, Uttar Pradesh, India

${ }^{2}$ Department of Animal Production, Maharana Pratap University of Agriculture and Technology, Udaipur- 313 001, Rajasthan, India

Dinesh Chandra Rai $(\bowtie)$

Department of Dairy Science and Food Technology, Institute of Agricultural Sciences, Banaras Hindu University, Varanasi- 221 005, UP, India

Email: dcrai@bhu.ac.in
}

nutrients (proteins, carbohydrates, fats, minerals, and vitamins). Milk is a suitable natural organic compound and extremely nutritive food and optimal for microbial growth. Therefore, due to the outgrowth of microorganisms into milk, its quality deteriorates and makes it less suitable for consumption (FAO, 2001). Microorganism impurity of raw milk can be eliminated by different methods like air, milking apparatus, feed, and fodder, dirt, and manure. Unfortunately, milk is among one of the most adulterated foods throughout the world (Kandapal et al. 2012; Kajal et al. 2012). The possible reasons behind adulteration may include economics of requirements and market availability, early perishable property of milk, low purchasing ability of consumers, and lack of rapid detection tests (Kamthania et al. 2014). The urbanization and high population growth in India increase the demand for milk which influences the possibility of adulteration to meet out this demand (Singh et al. 2015). The physicochemical analysis is an imperative method to examine the quality of milk and other milk-based dairy products. In the present study, milk samples were collected from different organized dairy farms of Varanasi, Uttar Pradesh, and analyzed for physicochemical, microbial, and adulteration parameters.

Cow, as well as buffalo raw milk samples, were collected randomly from different organized dairy farms around Varanasi, Uttar Pradesh. Thus, the raw milk samples were collected from seven different organized dairy farms with four replications of each sample. Altogether a total number of 28 samples of raw milk were analyzed. All raw milk samples $(500 \mathrm{~mL} /$ sample) were filled up aseptically from the bulk fresh raw milk cans and kept in sterilized plastic bottles and all raw milk samples were coded with random numbers. The raw milk constituents percent of fat, protein, lactose, solid not-fat (SNF), and specific gravity (SG) were determined as per AOAC (2005). The microbial quality, standard plate counts (SPC), and different mixed and hazardous chemicals adulterants of raw milk samples were analyzed according to FSSAI (2015).

Statistically, data analyzed by using the one-way analysis of variance (IBM SPSS software, version 21) for a completely randomized design. Significant differences $(\mathrm{P}<0.05)$ among treatments, within the experiment, were analyzed using Duncan's multiple range test. 
Fig. 1 Detection of different mixed and hazardous chemicals adulterants in cow and buffalo raw milk sample (The mean of values from 0.00 to -1.50 represents a negative value and from 0.00 to 1.00 represents the positive value of samples)

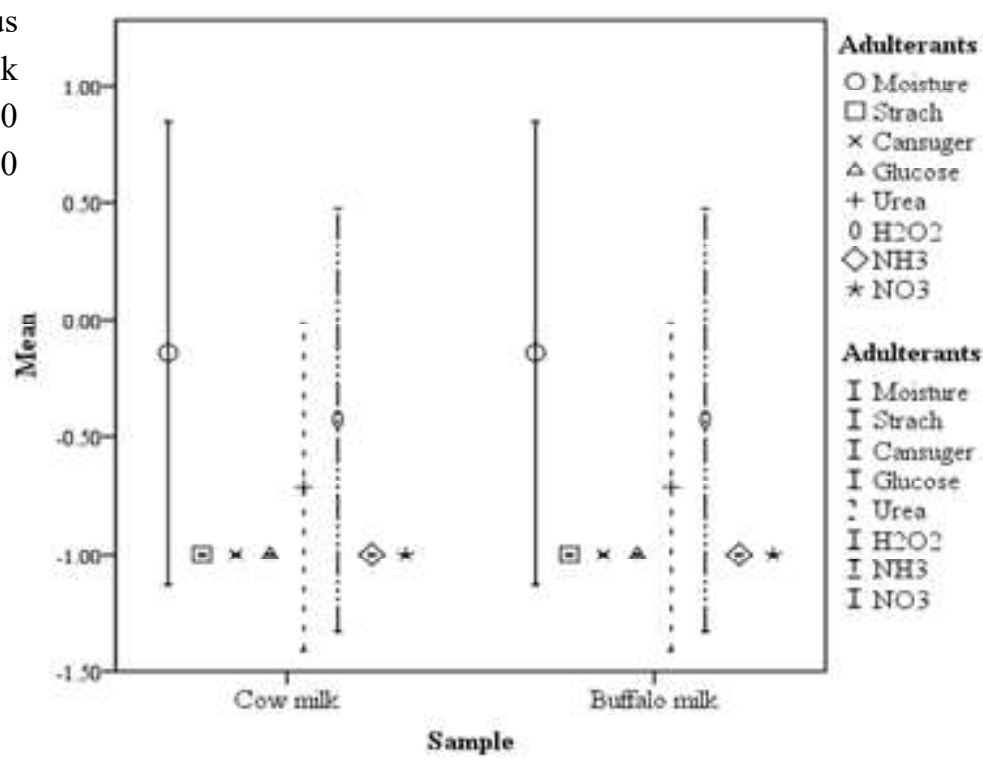

Table 1 Raw milk constituent indices, methylene blue reduction test (MBRT), and standard plate count (SPC) differences in cow and buffalo raw milk samples

\begin{tabular}{|c|c|c|c|c|c|c|c|c|c|c|}
\hline & Samples & 1 & 2 & 3 & 4 & 5 & 6 & 7 & SEM & P-value \\
\hline \multicolumn{11}{|c|}{ Milk constituents } \\
\hline \multirow[t]{2}{*}{ Fat $\%$} & Cow & $3.70^{\mathrm{a}}$ & $3.40^{\mathrm{b}}$ & $3.80^{\mathrm{a}}$ & $4.00^{\mathrm{a}}$ & $3.97^{\mathrm{a}}$ & $3.95^{\mathrm{a}}$ & $3.52^{\mathrm{ab}}$ & 0.06 & 0.061 \\
\hline & Buffalo & $7.00^{\mathrm{a}}$ & $6.77^{\mathrm{a}}$ & $6.82^{\mathrm{a}}$ & $6.92^{\mathrm{a}}$ & $6.45^{\mathrm{ab}}$ & $6.50^{\mathrm{ab}}$ & $6.00^{c}$ & 0.91 & 0.031 \\
\hline \multirow[t]{2}{*}{ Protein $\%$} & Cow & $3.42^{\mathrm{ab}}$ & $3.12^{\mathrm{c}}$ & $3.30^{\mathrm{ab}}$ & $3.62^{\mathrm{a}}$ & $3.52^{\mathrm{ab}}$ & $3.45^{\mathrm{ab}}$ & $3.20^{\mathrm{ab}}$ & 0.05 & 0.150 \\
\hline & Buffalo & $4.47^{\mathrm{a}}$ & $4.32^{\mathrm{a}}$ & $4.37^{\mathrm{a}}$ & $4.45^{\mathrm{a}}$ & $4.10^{\mathrm{ab}}$ & $3.87^{\mathrm{bc}}$ & $3.65^{\mathrm{c}}$ & 0.07 & 0.003 \\
\hline \multirow[t]{2}{*}{ Lactose $\%$} & Cow & $4.45^{\mathrm{a}}$ & $3.87^{\mathrm{b}}$ & $4.50^{\mathrm{a}}$ & $4.57^{\mathrm{a}}$ & $4.57^{\mathrm{a}}$ & $4.47^{\mathrm{a}}$ & $3.75^{\mathrm{b}}$ & 0.07 & 0.001 \\
\hline & Buffalo & $5.10^{\mathrm{a}}$ & $4.70^{\mathrm{a}}$ & $4.82^{\mathrm{a}}$ & $5.02^{\mathrm{a}}$ & $4.67^{\mathrm{a}}$ & $4.80^{\mathrm{a}}$ & $4.55^{\mathrm{a}}$ & 0.07 & 0.450 \\
\hline \multirow{2}{*}{$\begin{array}{l}\text { Solid not- } \\
\text { fat } \%\end{array}$} & Cow & $8.75^{\mathrm{a}}$ & $8.37^{\mathrm{b}}$ & $8.60^{\mathrm{ab}}$ & $8.40^{\mathrm{b}}$ & $8.42^{\mathrm{b}}$ & $8.75^{\mathrm{a}}$ & $8.32^{\mathrm{b}}$ & 0.04 & 0.011 \\
\hline & Buffalo & $9.20^{\mathrm{a}}$ & $8.92^{\mathrm{ab}}$ & $9.05^{\mathrm{a}}$ & $9.10^{\mathrm{a}}$ & $8.90^{\mathrm{ab}}$ & $8.82^{\mathrm{ab}}$ & $8.65^{\mathrm{b}}$ & 0.05 & 0.061 \\
\hline \multirow[t]{2}{*}{ Specific gravity } & Cow & $1.029^{\mathrm{a}}$ & $1.027^{\mathrm{bc}}$ & $1.028^{\mathrm{ab}}$ & $1.027^{\mathrm{bc}}$ & $1.027^{\mathrm{bc}}$ & $1.029^{\mathrm{a}}$ & $1.027^{\mathrm{bc}}$ & 0.00 & 0.063 \\
\hline & Buffalo & $1.030^{\mathrm{a}}$ & $1.030^{\mathrm{a}}$ & $1.030^{\mathrm{a}}$ & $1.030^{\mathrm{a}}$ & $1.029^{\mathrm{ab}}$ & $1.028^{\mathrm{c}}$ & $1.028^{\mathrm{c}}$ & 0.00 & 0.051 \\
\hline \multicolumn{11}{|c|}{ Microbial quality } \\
\hline MBRT & Cow & $4.15^{\mathrm{a}}$ & $3.82^{\mathrm{b}}$ & $3.80^{\mathrm{b}}$ & $4.00^{\mathrm{ab}}$ & $3.82^{\mathrm{b}}$ & $4.00^{\mathrm{ab}}$ & $4.15^{\mathrm{a}}$ & 0.03 & 0.001 \\
\hline (in hours) & Buffalo & $4.07^{\mathrm{a}}$ & $4.07^{\mathrm{a}}$ & $3.90^{\mathrm{a}}$ & $3.95^{\mathrm{a}}$ & $3.95^{\mathrm{a}}$ & $3.95^{\mathrm{a}}$ & $4.05^{\mathrm{a}}$ & 0.02 & 0.204 \\
\hline SPC & Cow & $2.70^{\mathrm{e}}$ & $3.35^{\mathrm{cd}}$ & $3.76^{\mathrm{b}}$ & $3.20^{\mathrm{d}}$ & $3.95^{\mathrm{b}}$ & $3.49^{\mathrm{c}}$ & $4.30^{\mathrm{a}}$ & 0.09 & 0.001 \\
\hline$(\log \mathrm{cfu} / \mathrm{ml})$ & Buffalo & $2.66^{\mathrm{d}}$ & $3.36^{\mathrm{bc}}$ & $3.59^{\mathrm{b}}$ & $3.11^{\mathrm{c}}$ & $4.02^{\mathrm{a}}$ & $3.35^{\mathrm{bc}}$ & $4.12^{\mathrm{a}}$ & 0.09 & 0.001 \\
\hline
\end{tabular}

$\mathrm{a}, \mathrm{b}, \mathrm{c}, \mathrm{d}$, and e means with the same letters in the same row are non significantly different $(\mathrm{P}<0.05)$

The results (Table 1) showed that the fat content of cow milk revealed that the highest $(\mathrm{P}<0.05)$ fat content was noted in sample no. $4(4.00 \pm 0.135 \%)$ followed by sample no. sample no. 5

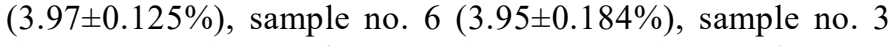

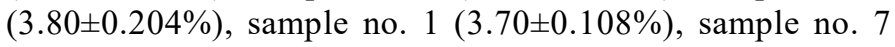
$(3.52 \pm 0.125 \%)$, and sample no. $2(3.40 \pm 0.147 \%)$, respectively whereas on other hand the fat content of buffalo milk was recorded significantly $(\mathrm{P}<0.05)$ higher in sample no. $1(7.00 \pm 0.108 \%)$ followed by sample no. sample no. 4 (6.92 $\pm 0.232 \%)$, sample no. 3 $(6.82 \pm 0.295 \%)$ and sample no. $2(6.77 \pm 0.149 \%)$ significantly similar with sample no. 1 . The lower raw milk fat content was recorded in sample no. $7(6.00 \pm 0.147 \%)$ which was numerically similar to the raw milk fat content of sample $5(6.45 \pm 0.266 \%)$, sample no. 6 $(6.50 \pm 0.147 \%)$, respectively. In this present study, all cow and buffalo raw milk samples find out a satisfactory requirement according to FASSI regulations (2011). The present findings are in agreement with Bailone et al. (2017), Alam et al. (2018), Gupta et al. (2020), and Becskei et al. (2020) recorded average fat content between 3.70 to $5.97 \%$ in different breeds of cows and buffaloes. The maximum protein content of cow milk was noted numerically in sample $4(3.62 \pm 0.110 \%)$ whereas raw milk protein content of samples no. 1, 3, 5, 6, and 7 were found to be numerically at par with each other, respectively. Buffalo raw milk protein content was noted significantly $(\mathrm{P}<0.05)$ higher in sample $1(4.47 \pm 0.085 \%)$ 
followed by lower protein content was noted in sample no.7 (3.65 $\pm 0.125 \%)$ and samples no. 2, 3, 4, 5, and 6 was recorded to be numerically at par with each other (Table 1). The outcomes are similar to the reports of Tesfay et al. (2015), Bailone et al. (2017), and Karmaker et al. (2020) whose research also finds out the raw milk protein content of cows and buffaloes averagely between 3.20 to $3.42 \%$ and 3.70 to $4.40 \%$ as well. In the current findings (Table 1), the significantly $(\mathrm{P}<0.05)$ highest lactose content of cow raw milk was found out both in samples no. 4 and 5 $(4.57 \pm 0.193 \%)$ which was followed by sample no. $6(4.47 \pm 0.149 \%)$, sample no. $1(4.45 \pm 0.132 \%)$ and sample no. $2(3.87 \pm 0.047 \%)$. The lowest raw milk lactose content was noted in sample no. 7 $(3.75 \pm 0.104 \%)$. However, the lactose content of buffalo raw milk did not differ $(\mathrm{P}<0.05)$ from each other. Similar results were obtained in the different studies the average lactose content from 4.42 to $4.87 \%$ shown by Bailone et al. (2017), Gupta et al. (2020), and Karmaker et al. (2020). Solid not-fat (SNF) present in cow milk was higher in the sample no. 1 and 6 with $(8.75 \pm 0.064 \%)$ but non-significant and the buffalo raw milk SNF content finds highest in the sample no. $1(9.20 \pm 0.122 \%)$ among all the samples, respectively (Table 1). The present finding is similar with an average mean value of raw milk SNF content as $8.76 \%$ in cows and from 8.80 to $9.13 \%$ in the different Indian buffalo breeds that were reported by Mishra et al. (2008) and Kader et al. (2015). The specific gravity (SG) in the cow as well as buffalo raw milk were not significantly different among all raw samples and show variation between $1.027 \pm 0.000$ to $1.029 \pm 0.000$ in cow raw milk and from $1.028 \pm 0.000$ to $1.030 \pm 0.000$ in buffalo raw milk respectively (Table 1). The current finding of the SG in different cow and buffalo raw milk samples was found out to be similar, observed that highest mean value of specific gravity of milk sample as $1.030 \pm 0.039$ and minimum value $1.027 \pm 0.001$ reported by(Mahmood and Usman, 2010 and Payasi and Poonia, 2015). During the experimental period, raw milk MBRT (in hours) quality significantly retained maximum-minimum period $(4.15 \pm 0.064$ to $3.80 \pm 0.040 \mathrm{hrs}$ ) to change raw milk samples dye color from blue to white which showed that this cow raw milk sample comes under good quality and however all buffalo raw milk MBRT samples non-significantly retained maximum-minimum period ( $4.07 \pm 0.047$ to $3.90 \pm 0.040 \mathrm{hrs}$ ) with under good quality milk (Table 1). The present result agreed with (Gupta et al. 2020) reported that the average maximum-minimum period was 4.0 to 3.0 hours for the change its color from blue to white, which indicates that this milk sample comes under good quality. The significantly lower SPC of raw milk sample was recorded into sample no. 1 $(2.70 \pm 0.084 \log \mathrm{CFU} / \mathrm{ml})$ in cow raw milk and sample no. 1 (2.66 $\pm 0.077 \log$ CFU/ml) in buffalo raw milk respectively (Table 1). The present study findings are agreed along within the range of 3.0 to $5.20 \mathrm{CFU} / \mathrm{ml}$ microbial loads reported by (Bailone et al. 2017 and Karmaker et al. 2020).

The results of different adulteration tests such as added starch, cane sugar, and glucose as well as different hazardous chemical adulterants such as Urea, hydrogen peroxide $\left(\mathrm{H}_{2} \mathrm{O}_{2}\right)$, ammonium
$\left(\mathrm{NH}_{3}\right)$, and Nitrates $\left(\mathrm{NO}_{3}\right)$ was recorded as negative responses for both cow and buffalo raw milk samples, only moisture content was found out the positive response in some samples (Fig. 1), which indicates that raw milk was free from different mixed adulteration and hazardous chemicals adulterant contents. In our present study findings, results also agreed with other researchers (Pandey et al. 2019; Gupta et al. 2020 and Karmaker et al. 2020).

\section{Conclusion}

Varanasi is a holy city and a huge amount of milk is consumed for rituals and sweets based on Chhana and Khoa. Most of the milk is procured directly from Dudh Mandi as well as organized farms. During the investigation, different organized dairy farms were studied for the compositional and microbial status of both cow and buffalo milk. Most of the parameters were within the conformity of FSSAI guidelines. Raw milk quality was excellent and free from adulteration except for some samples.

\section{References}

Alam S, Zaman MA, Roy S, Ahmed J, Das M, Chowdhury QMML, Proma SD, Popy FY (2018) Evaluation of physio-chemical properties of locally produced raw milk in Sylhet city corporation area, Bangladesh. Asian Food Sci J 3: 1-6

AOAC (2005) FDA Bacteriological Analytical Manual, $18^{\text {th }}$ ed., AOAC: Gaithersburg, MD, USA

Bailone RL, Borra RC, Roca RDO, Aguiar LD, Harris M (2017) Quality of refrigerated raw milk from buffalo cows (Bubalus bubalis bubalis) in different farms and seasons in Brazil. Cienc Anim Bras Goiania 18: $1-12$

Becskei Z, Savic M, Cirkovic D, Raseta M, Puvaca N, Pajic M, Dordevic S, Paskas S (2020) Assessment of water buffalo milk and traditional milk products in a sustainable production system. Sustainability 12 : 6616

FAO (2001) The lactoperoxidase system of milk preservation. Regional Lactoperoxidase workshop in West Africa. Burkina Faso

FSSAI (2011) Food products standards and food additives regulations. https://archive.fssai.gov.in

FSSAI (2015) Manual for analysis of milk and milk products. https:// archive.fssai.gov.in

Gupta PK, Rai DC, Paswan VK, Panta R, Yadav AK (2020) Study on Physico-chemical and microbial quality of raw milk collected from different places of Assi region in Varanasi city, Varanasi. Asian J Dairy Food Res 39: 1-9

Kader A, Deb M, Aziz MA, Sohag MMH, Rahman SR (2015) Evaluation of Physico-chemical properties and microbiological quality of milk collected from different dairy farms in Sylhet, Bangladesh. Food Sci Tech 3: 37-41

Kajal MFI, Wadud A, Islam MN, Sarma PK (2012) Evaluation of some chemical parameters of powder milk available in Mymensingh town. J Bangladesh Agric Uni 10: 95-100

Kamthania M, Saxena J, Saxena K, Sharma DK (2014) Methods of detection and remedial measures. Int J Engg Tech Res 1: 15-20

Kandpal SD, Srivastava AK, Negi KS (2012) Estimation of quality of raw milk (open and branded) by milk adulteration testing kit. Indian J Comm Health 24: 188-192 
Karmaker A, Das PC, Iqbal A (2020) Quality assessment of different commercial and local milk available in the local markets of the selected area of Bangladesh. J Adv Vet Anim Res 7: 26-33

Mahmood A, Usman S (2010) A comparative study on the physicochemical parameters of milk samples collected from buffalo, cow, goat, and sheep of Gujarat. Pakistan J Nutr 12: 1192-1197

Misra SS, Sharma A, Bhattacharya TK, Kumar P, Saha RS (2008) Association of breed and polymorphism of $\alpha$-s 1 and $\alpha$-s2casein genes with milk quality and daily milk and constituent yield traits of buffaloes (Bubalus bubalis). Buffalo Bull 27: 294-301
Pandey AK, Shakya S, Ali SL, Bhonsle D, Chandrakar C, Khan R (2019) A study on detection of adulteration in milk samples from two districts of Chhattisgarh state. J Anim Res 9: 491-493

Payasi A, Poonia A (2015) Physico-chemical and microbiological quality of milk sold in milk markets (Doodh mandi) of Varanasi district, Uttar Pradesh. Indian J Dairy Sci 68: 458-462

Singh J, Roy B, Dayal G, Sunsunwal S, Yadav B, Bhardwaj C, Teotia A (2015) Detection of common adulterants in milk from Delhi and NCR. Delhi Univ J Undergraduate Res Innovation 1: 152-156

Tesfay T, Kebede A, Seifu E (2015) Physicochemical properties of cow milk produced and marketed in Dire Dawa town, Eastern Ethiopia. Food Sci Quality Management. 42: 56-61 